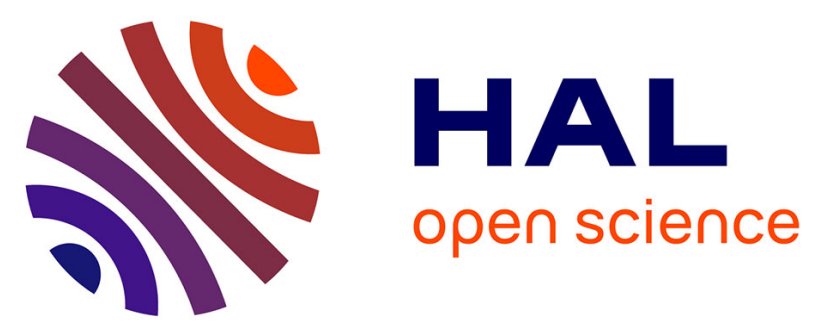

\title{
Intraabdominal urokinase in the treatment of loculated infected ascites in cirrhosis.
}

\author{
Simona Tripon, Pierre Mayer, Axenia Svab, Francois Habersetzer, Patrick \\ Pessaux, Thomas F. Baumert, Iulian Enescu
}

\section{- To cite this version:}

Simona Tripon, Pierre Mayer, Axenia Svab, Francois Habersetzer, Patrick Pessaux, et al.. Intraabdominal urokinase in the treatment of loculated infected ascites in cirrhosis.. Clinics and Research in Hepatology and Gastroenterology, 2020, S2210-7401 (20), pp.30181-9. 10.1016/j.clinre.2020.06.012 . hal-02956538

\section{HAL Id: hal-02956538 \\ https://hal.science/hal-02956538}

Submitted on 2 Oct 2020

HAL is a multi-disciplinary open access archive for the deposit and dissemination of scientific research documents, whether they are published or not. The documents may come from teaching and research institutions in France or abroad, or from public or private research centers.
L'archive ouverte pluridisciplinaire HAL, est destinée au dépôt et à la diffusion de documents scientifiques de niveau recherche, publiés ou non, émanant des établissements d'enseignement et de recherche français ou étrangers, des laboratoires publics ou privés. 
Elsevier Editorial system(tm) for Clinics and Research in Hepatology and Gastroenterology

Manuscript Draft

Manuscript Number: CLINRE-D-20-00469

Title: Intraabdominal urokinase in the treatment of loculated infected ascites in cirrhosis

Article Type: Case report

Corresponding Author: Dr. Simona TRIPON,

Corresponding Author's Institution: Nouvel Hopital Civil, Hôpitaux Universitaires de Strasbourg

First Author: Simona TRIPON

Order of Authors: Simona TRIPON; Pierre MAYER; Axenia SVAB; François HABERSETZER; Patrick PESSAUX; Thomas F BAUMERT; Iulian Enescu

Abstract: Cirrhotic patients may present loculated ascites. We report a case of a 49-years old patient with cirrhosis and loculated infected ascites. Conventional and ultrasound (US)-guided paracentesis were ineffective. Moreover, US-guided drainages with 10 F drains could drain only small quantities of ascites localized in the largest loculated areas. Despite an adapted and long antibiotic therapy, the infection persisted. Intraabdominal fibrinolysis allowed the destruction of the fibrin septa, a better drainage and the sterilization of the ascites fluid. This is the first case report of effective intraabdominal fibrinolysis with urokinase in difficult to treat loculated infected ascites. 


\section{Conflict of interest statement}

\section{Declaration of interests}

$\bigotimes$ The authors declare that they have no known competing financial interests or personal relationships that could have appeared to influence the work reported in this paper.

$\square$ The authors declare the following financial interests/personal relationships which may be considered as potential competing interests:

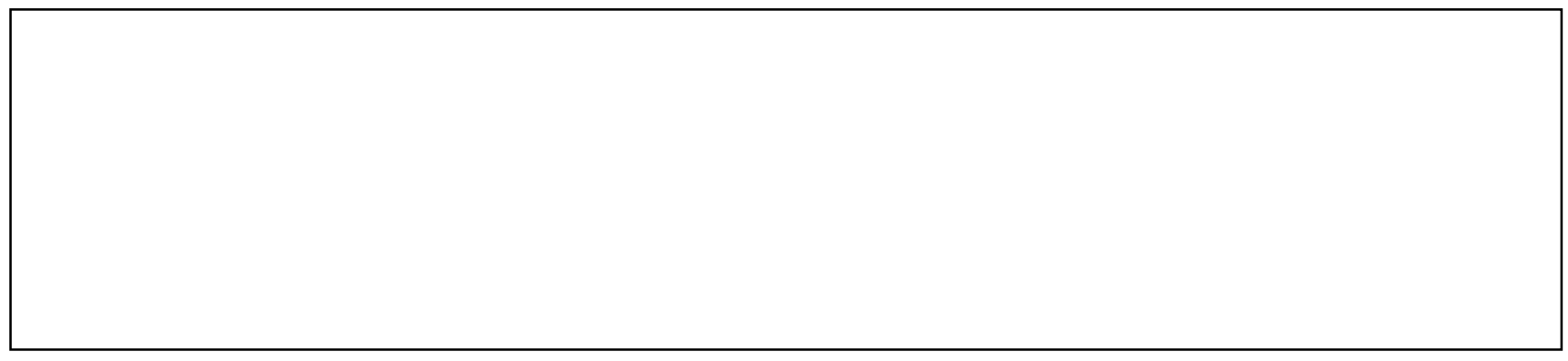


Intraabdominal urokinase in the treatment of loculated infected ascites in cirrhosis

Simona TRIPON ${ }^{1,2}$, Pierre MAYER ${ }^{1}$, Axenia SVAB ${ }^{1}$, François HABERSETZER ${ }^{1,2}$, Patrick PESSAUX ${ }^{1,2}$, Thomas F BAUMERT ${ }^{1,2}$, Iulian ENESCU ${ }^{3}$

1. Pôle hépato-digestif, Nouvel Hôpital Civil, Hôpitaux Universitaires de Strasbourg, France

2. Unité INSERM UMR-S1110, Institut de Recherche sur les Maladies Virales et Hépatiques

3. Service de Radiologie Interventionnelle, Nouvel Hôpital Civil, Hôpitaux Universitaires de Strasbourg, France

\section{Corresponding author}

\section{Dr Simona TRIPON}

Pôle hépato-digestif, Nouvel Hôpital Civil, Hôpitaux Universitaires de Strasbourg,

1er Place de l’Hôpital, Strasbourg, France

Tel: +330369550842

Fax: + 330369551857

Email: simona.tripon@chru-strasbourg.fr

\section{Abstract}


Cirrhotic patients may present loculated ascites. We report a case of a 49 -years old patient with cirrhosis and loculated infected ascites. Conventional and ultrasound (US)-guided paracentesis were ineffective. Moreover, US-guided drainages with $10 \mathrm{~F}$ drains could drain only small quantities of ascites localized in the largest loculated areas. Despite an adapted and long antibiotic therapy, the infection persisted. Intraabdominal fibrinolysis allowed the destruction of the fibrin septa, a better drainage and the sterilization of the ascites fluid.

This is the first case report of effective intraabdominal fibrinolysis with urokinase in difficult to treat loculated infected ascites.

\section{Introduction}

Ascites is the most common complication of cirrhosis. It affects $5-10 \%$ of compensated cirrhosis per year having a poor prognosis with 2-years mortality of $40 \%$ (1). Spontaneous bacterial peritonitis (SBP) is a severe complication of decompensated cirrhosis. In spite the widespread of antibiotics, the mortality is high ranging from 10 to $46 \%(2,3)$.

Cirrhotic patients may develop loculated ascites. In these patients the paracentesis is ineffective. Moreover, the SBP is difficult to treat because of the presences of the fibrin strands that impair the antibiotic diffusion. Patients with SBP and loculated ascites are at high risk of acute-on-chronic liver failure (ACLF) and mortality in absence of a quick and optimal treatment.

Keywords: loculated ascites, fibrinolysis

\section{Case report}


We report a case of a 49-year-old man with cirrhosis secondary to hepatitis B, C and alcohol consumption. His past medical history was insignificant.

Hepatitis C was cured in 2017 by direct-acting antiviral treatment and the alcohol consumption was stopped 6 months before. Hepatitis B DNA was $4810 \mathrm{UI} / \mathrm{ml}$ and a nucleotide analog treatment was introduced during the hospitalization.

The cirrhosis was complicated by portal hypertension: esophageal varices and refractory ascites that required paracentesis every two weeks.

He was admitted to emergency room for abdominal pain and dyspnea secondary to ascites decompensation. He was transferred in the Hepatology Unit thereafter. At admission, the blood tests showed an elevated C-reactive protein $95 \mathrm{mg} / \mathrm{L}$ (normal $<0.4 \mathrm{mg} / \mathrm{dL}$ ) and the white cell count was $8.33 \times 10^{9} / \mathrm{L}$ (reference range $4.10-10.5 \times 10^{9} / \mathrm{L}$ ). The cirrhosis was classified Child-Pugh B -9 points, MELD 8. The contrast-enhanced CT scan showed a large quantity of ascites localized predominantly in right abdomen associated with a diffuse thickening of peritoneal lining in favor of peritonitis (Figure 1). The culture from the ascites was negative and the neutrophil count was $<250 / \mathrm{mm}^{3}$. The paracentesis removed only small quantities of liquid due to the loculation of ascites caused by the presence of fibrin strands. At day 7, the C- reactive protein level enhanced at $178 \mathrm{mg} / \mathrm{L}$ (normal $<0.4 \mathrm{mg} / \mathrm{dL}$ ). The ascites cultures isolated Enterococcus faecium (E. faecium), but the neutrophil count was less than $250 / \mathrm{mm}^{3}$. An antibiotic therapy by vancomycin was initiated for treating the bacterascites.

Three ultrasound guided drainages were performed using 10F drains in order to evacuate a large volume of ascites, but only small quantities of ascites were evacuated (max. $400 \mathrm{ml}$ ) because of the loculated ascites (Figure 2 and 3 ). 
Despite well conducted antibiotic therapy, after 20 days of treatment, some cultures from the ascites fluid remained positive at $E$. faecium and the neutrophil count increased at $11900 / \mathrm{mm}^{3}$ (normal $<250 / \mathrm{mm}^{3}$ ) which was in favor of a spontaneous bacterial peritonitis (SBP). Moreover, two diagnostic paracenteses were realized at the same time with different localizations. The neutrophil count of the samples was different, and the microbiological study revealed the presence of $E$. faecium in the first one, and negative in the second one.

The multidisciplinary board decided to perform the intraabdominal fibrinolysis by urokinase in order to destruct the fibrin strandings, to facilitate the ascites drainage and the antibiotics diffusion.

Two drains were positioned in the right abdominal cavity and 100000 UI of Urokinase was administrated in each one. The drains were clamped 5 hours after Urokinase administration, and the drainage was left for 48 hours. Three litres of ascites were evacuated and compensated by albumin infusion according to EASL recommendations (4).

Ascites aspect was sero-sanguine, and the haemoglobin reduced progressively at $6.9 \mathrm{~g} / \mathrm{dl}$ (reference range 13.8-18) that represented a loss of $1.3 \mathrm{~g} / \mathrm{dl}$, without hemodynamic instability. The patient was transfused of 2 red blood units. There was no complication during and after the procedure. The ultrasound examination revealed a significative reduction of the ascites volume and the fibrin strands (Figure $4 \mathrm{~A}$ and $4 \mathrm{~B}$ ). Although the procedure could be repeated, we decided to apply it once.

At day 14 after fibrinolysis, the patient had mild clinical ascites. Many ascites analyses in this interval were negatives. The ascites samples collected at 2 weeks post drainage showed the neutrophil count $<250 / \mathrm{mm}^{3}$ and negatives cultures. Secondary prophylaxis by norfloxacin was initiated. 
Five months after the procedure, the ascites was controlled by mild doses of diuretics. The patient had no recurrence of SBP or bacterascites and no need of paracentesis (Figure 5).

\section{Discussion}

Ascites is a major complication of cirrhosis. It is multifactorial and seems to result from the combination of portal hypertension and liver insufficiency (5). In cirrhotic patients, ascites is primarily a transudative fluid with poor opsonic activity which provides a favorable environment for growth of bacteria (6).

SBP is the most frequent bacterial infection in patients with cirrhosis and ascites. The prevalence ranges from $10 \%$ to $30 \%$ in hospitalized patients. Half of the episodes are present at the time hospitalization, while the rest are acquired during hospitalization $(3,7)$. These patients have hemodynamic dysfunction and once SBP develops, there is an excessive response of pro-inflammatory cytokines leading to serious complications such as renal failure, shock, ACLF characterized by a high mortality due to multiorgan failure. One-year mortality rate after a first episode of SBP is high ranging from $30 \%$ to $93 \%$ regardless of its recurrence (3).

Many patients with cirrhosis develop loculated ascites, but the mechanism is unknown. Stanley et al, reported one mechanism in cirrhotic patients with peritoneovenous shunts. It was hypothesized that these patients have a faster ascites fluid circulation with a high release of fibrogenic cytokines that may increase the fibrin deposition on the peritoneum and converts fibrinous adhesions to generalized peritoneal fibrosis (8). 
Loculated ascites has been described in patients with peritonitis. In the bacterial peritonitis, activity of the plasminogen activator inhibitor type 1 and 2 (PAI-1 and PAI 2) and decreased activity of the activators such as tissue type plasminogen activator (tPA). The reduced local fibrinolysis may lead to fibrin deposition in the abdominal cavity, that acts as a nidus for bacterial grows leading to abscess formation (9).

Van Veen and al. showed successful use of recombinant tissue plasminogen activator (r-tPA) in polymicrobial peritonitis in mice. The effect was dose dependent, higher dose was more effective to cleave the intraabdominal fibrin deposition and reduce the bacterial load. Moreover, high-dose of r-tPA lavage reduces the production of pro-inflammatory cytokine, IL-12 and increased the anti-inflammatory cytokine such as IL-10 that play a protective role in sepsis $(10,11)$.

In patients with cirrhosis, there is a continue debate on the fibrinolytic status which may be easily disturbed. It has been reported that these patients have an elevated tPA and a decreased level of antifibrotic proteins (antiplasmin, thrombin-activable fibrinolysis inhibitor) leading to a hyperfibrinolytic state (12). Moreover, patients with ascites without sepsis or SBP had a hyperfibrilolytic state (13). In the literature $(12,14)$, it was showed that cirrhotic patients with sepsis had hypofibrinolysis which may increase the risk thrombotic complications leading to hepatic and extrahepatic organ failure associated with short-term mortality. Indeed, in patients with sepsis, the inflammation induces an enhanced release of PAI-1 by the endothelial cells that is associated with a decreased fibrinolysis. Interestingly, when sepsis develops, patients may shift rapidly from a hyperfibrinolytic state to a hypofibrinolytic state. 
Pleural infection is associated with fibrin deposition over the visceral and parietal pleura leading to loculated collections. In these patients, intrapleural fibrinolysis is recommended in order to avoid surgical intervention. Fibrinolytic agents such as streptokinase or urokinase are used in patients with pleural empyema for decreasing the formation of intrapleural fibrous bands or the viscosity of empyema pus to promote the drainage. Urokinase, a direct plasminogen activator, was isolated from human urine. Actually, it is obtained from cultured human embryonic kidney cells. The advantage is that it is not antigenic and its efficacy is not reduced by antibody production. Moreover, the use of urokinase should be favored in patients with hemostatic disorders. Usually, $100000 \mathrm{IU}$ diluted with $30-100 \mathrm{ml}$ of normal saline is administrated intrapleural daily for 3 to 5 days. The drain is clumped 2-4 $\mathrm{h}$ after the instillation before water-seal or drainage. The principal side effect that was reported is intrapleural hemorrhage $(15,16,17)$.

In our case, the ascites was very difficult remove by paracentesis because of the presence of the fibrin stands. Moreover, the cultures from ascites fluid remained positives despite adapted antibiotics that showed a difficult diffusion. Our multidisciplinary board decided to perform intraabdominal fibrinolysis with urokinase in order to dissolve the fibrin septa, facilitate the antibiotic diffusion and ascites drainage.

To our knowledge, this is the first case that reported the successful utilization of intraabdominal urokinase in patients with persistent infection due to loculated ascites by the fibrin strands. The fibrinolysis may release viable bacteria from the dissolving fibrin septa $(18,19)$. The drainage of the ascites associated with a better diffusion of antibiotics after the destruction of the fibrin strands may reduce the abscess formation and thereby the morbidity and mortality. There was no complication during and after the fibrinolysis. 
In conclusion, intraabdominal administration of urokinase is effective and safe in cirrhotic patients with SBP. Intraperitoneal fibrinolysis in combination with appropriate antibiotic treatment and drainage may be considered in the management of difficult to treat loculated infected ascites.

The patient gave his consent to use the clinical data and photographs for this scientific publication.

\section{References}

1. D'Amico G, Pasta L, Morabito A, et al. Competing risks and prognostic stages in cirrhosis: a 25-year inception cohort study of 494 patients. Aliment Pharmacol Ther. 2014; 39 (10): 1180-1193.

2. Rimola A, Garcia-Tsao G, Navasa M, et al. Diagnosis, treatment and prophylaxis of spontaneous bacterial peritonitis: a consensus document. International Ascites Club. J Hepatol 2000; 32: 142-153.

3. Bunchorntavakul C, Chamroonkul N, Chavalitdhamrong D. Bacterial infections in cirrhosis: A critical review and practical guidance. World Journal of Hepatology 2016; 28: 8(6): 307-321.

4. The European Association for the Study of the Liver. EASL Clinical Practice Guidelines for the management of patients with decompensated cirrhosis. J Hepatol 2018, https://doi.org/10.1016/j.jhep.2018.03.024

5. Rudler M, Mallet M, Sultanik P, et al. Optimal management of ascites. Liver Int 2020 ; 40 (Suppl. 1) : 128-135. 
6. Dever JB, Sheikh MY. Review article: spontaneous bacterial peritonitis - bacteriology, diagnosis, treatment, risk factors and prevention. Aliment Pharmacol Ther 2015; 41: $1116-1131$.

7. Evans LT, Kim WR, Poterucha JJ, Kamath PS. Spontaneous bacterial peritonitis in asymptomatic outpatients with cirrhotic ascites. Hepatology 2003 ; 37: 897-901.

8. Stanley MM, Reyes CV, Greenly HB. Et al. Peritoneal fibrosis in cirrhotic treated with peritoneovenous shunting for ascites : an autopsy study with clinical correlation. Dig Dis Sci $1996 ; 41: 571-581$.

9. Ince A, Erlogu A, Tarhan O, Bulbul A. Peritoneal fibrinolytic activity in peritonitis. Am J Surg $2002 ; 183: 67-69$.

10. Kahlke V, Dohm C, Mees T, et al. Early interleukin-10treatment improves survival and enhanced immune function only in males after hemorrhage and subsequent sepsis. Shock 2002; 18: 24-28.

11. Van Veen SQ, Meijers JCM, Levi M, et al. Effects of intra-abdominal administration of recombinant tissue plasminogen activator on coagulation, fibrinolysis and inflammatory responses in experimental polymicrobial peritonitis. Shock 2007; 25 (5): 543-541.

12. Blasi A, Patel VC, Adelmeidjer M, et al. Mixed Fibrinolytic Phenotypes in Decompensated Cirrhosis and Acute-on-Chronic Liver Failure with Hypofibrinolysis in Those With Complications and Poor Survival. Hepatology 2019 Aug 29. doi: 10.1002/hep.30915 PMID:31465557.

13. Agarwal S, Joyner KA Jr, Swaim MW. Ascites fluid as a possible origin for hyperfibrinolysis in advanced liver disease. Am J Gastroenterol 2000;95:3218-3224.

14. Gando S. Role of fibrinolysis in sepsis. Semin Thromb Hemost 2013;39:392-399. 
15. Bouros B, Tzouvelekis A, Antoniou KM, Heffner JE. Intrapleural fibrinolytic therapy for pleural infection. Pulm Pharmacol Ther 2007 ; 20 (6) : 616-626.

16. Janda S, Swiston J. Intrapleural Fibrinolytis. Therapy for treatment of Adult Parapneumonoc Effusions and Empyemas. Chest 2012 ; 142 (2) : 401-411.

17. Bedat B, Plojoux J, Jade N, et al. Comparison of intrapleural use of urokinase and tissue plasminogen activator/DNAse in pleural infection. ERJ Open Res 2019 ; Sep 10;5(3). pii: 00084-2019.

18. Rotstein OD, Kao J: Prevention of intra-abdominal abscesses by fibrinolysis using recombinant tissue plasminogen activator. J Infect Dis 1988 ; 158: 766-772.

19. McRitchie DI, Cummings D, Rotstein OD : Delayed administration of tissue plasminogen activator reduces intra-abdominal abscess formation. Arch Surg $1989 ; 124: 1406-1410$. 
Figure 1.

Click here to download high resolution image

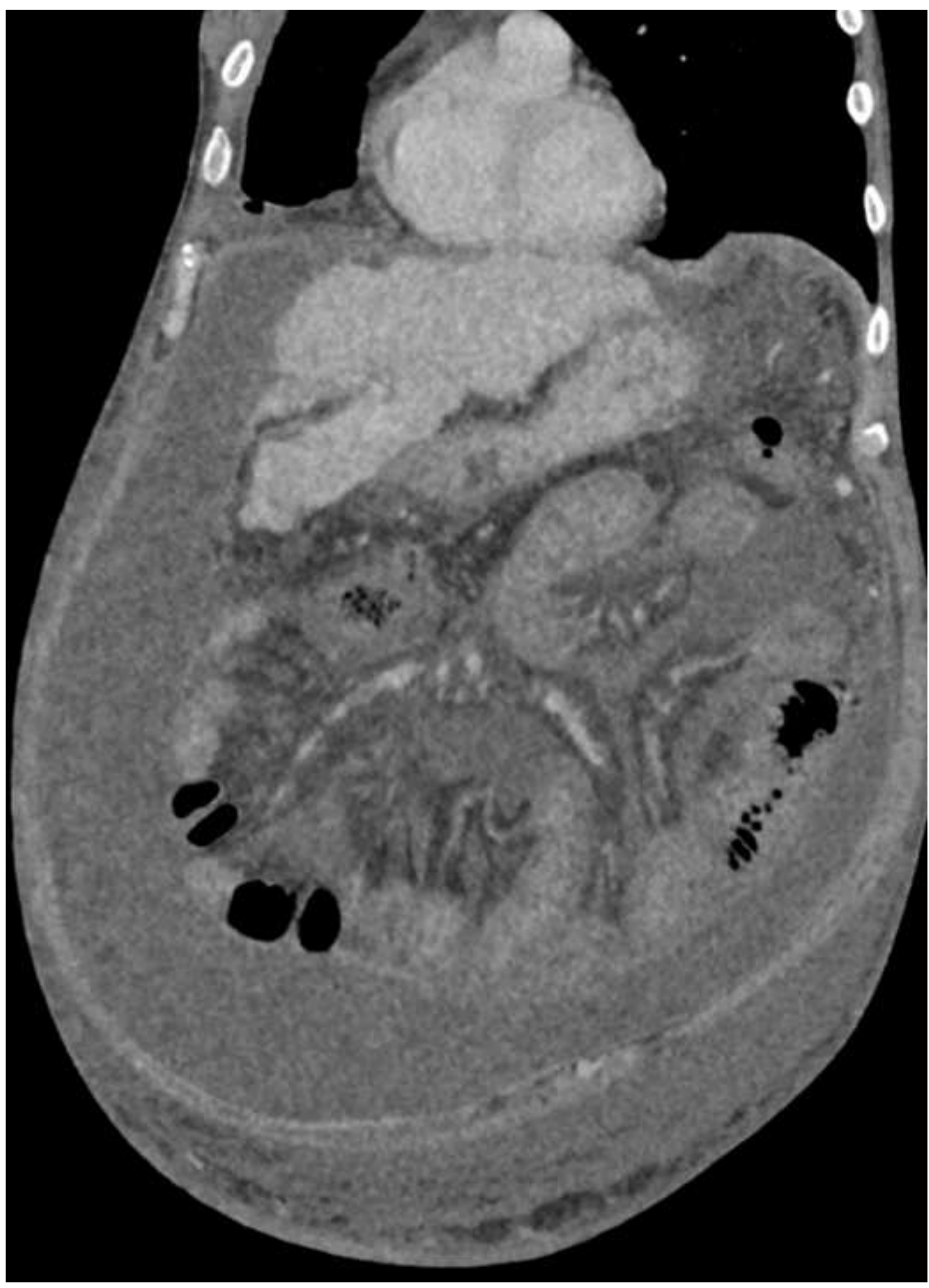


Figure 2.
Click here to download high resolution image

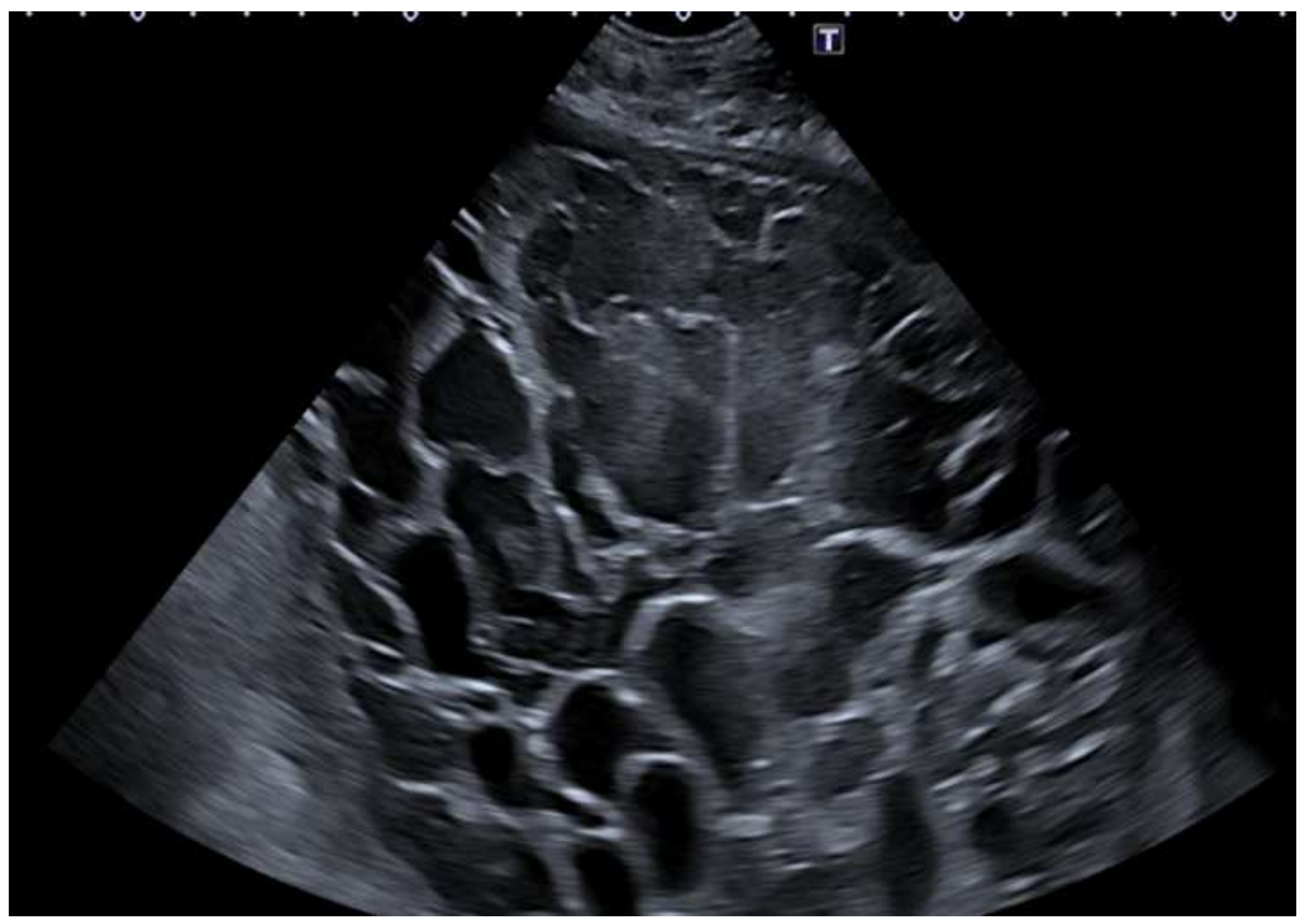


Figure 3.

Click here to download high resolution image

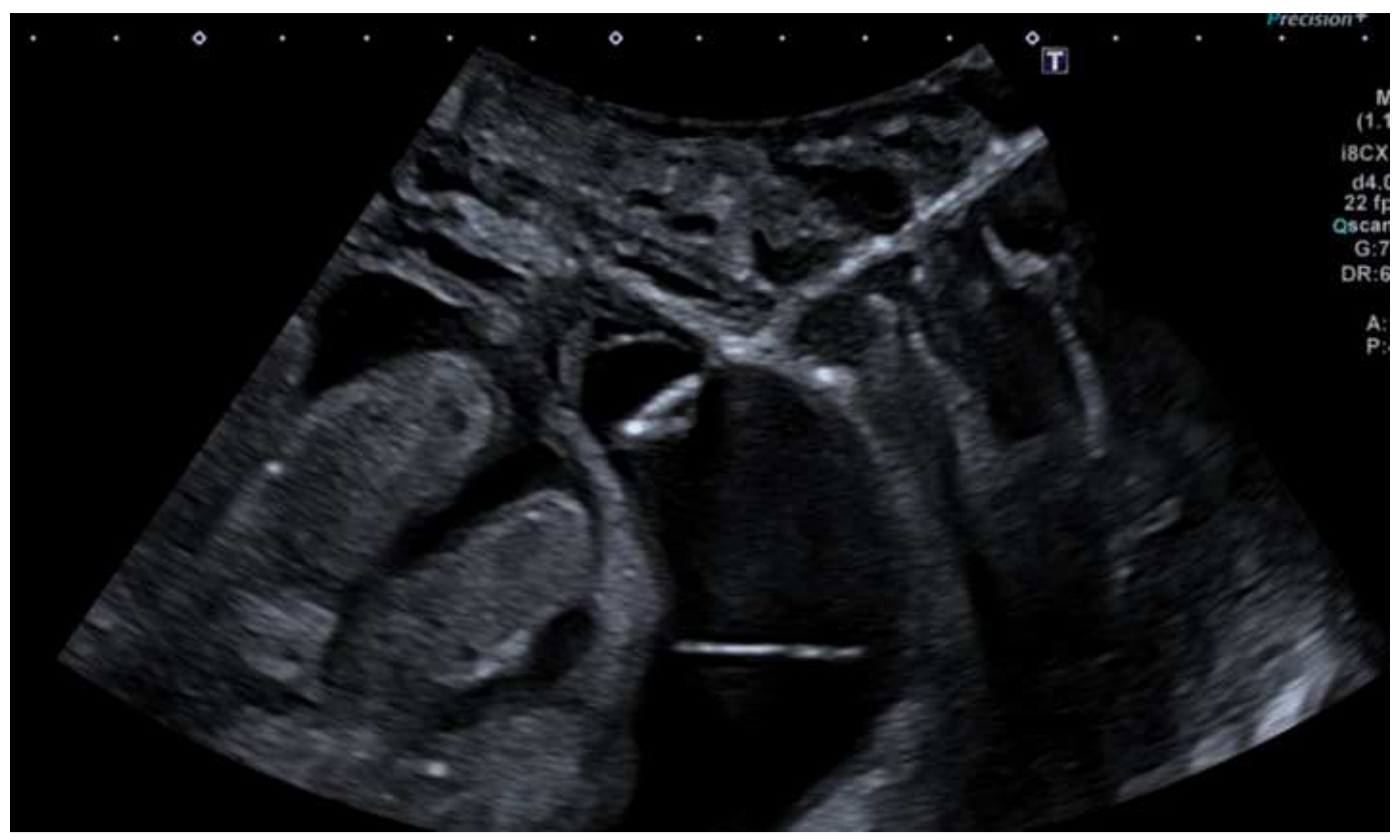


Click here to download high resolution image

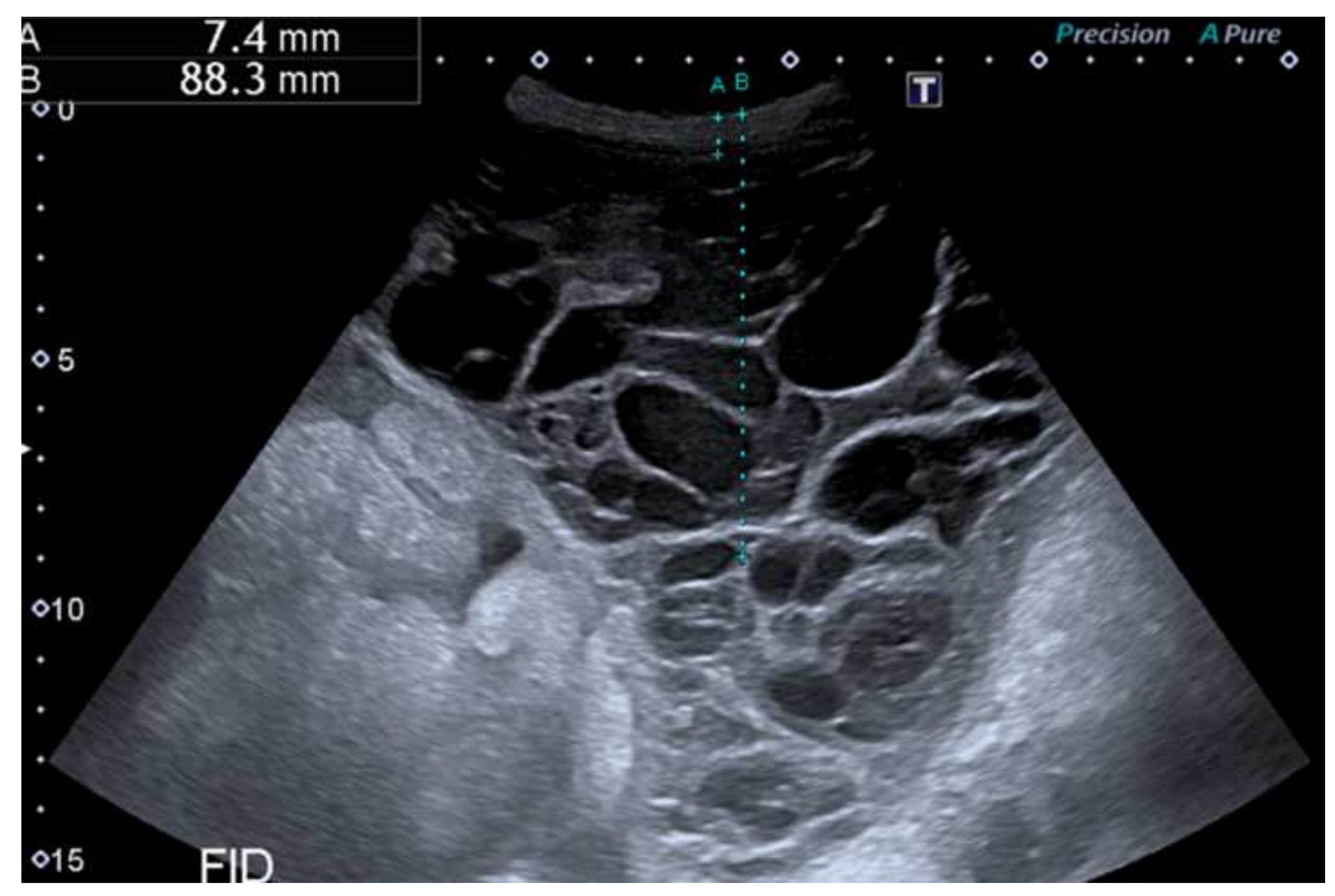


Figure 4B.
Click here to download high resolution image

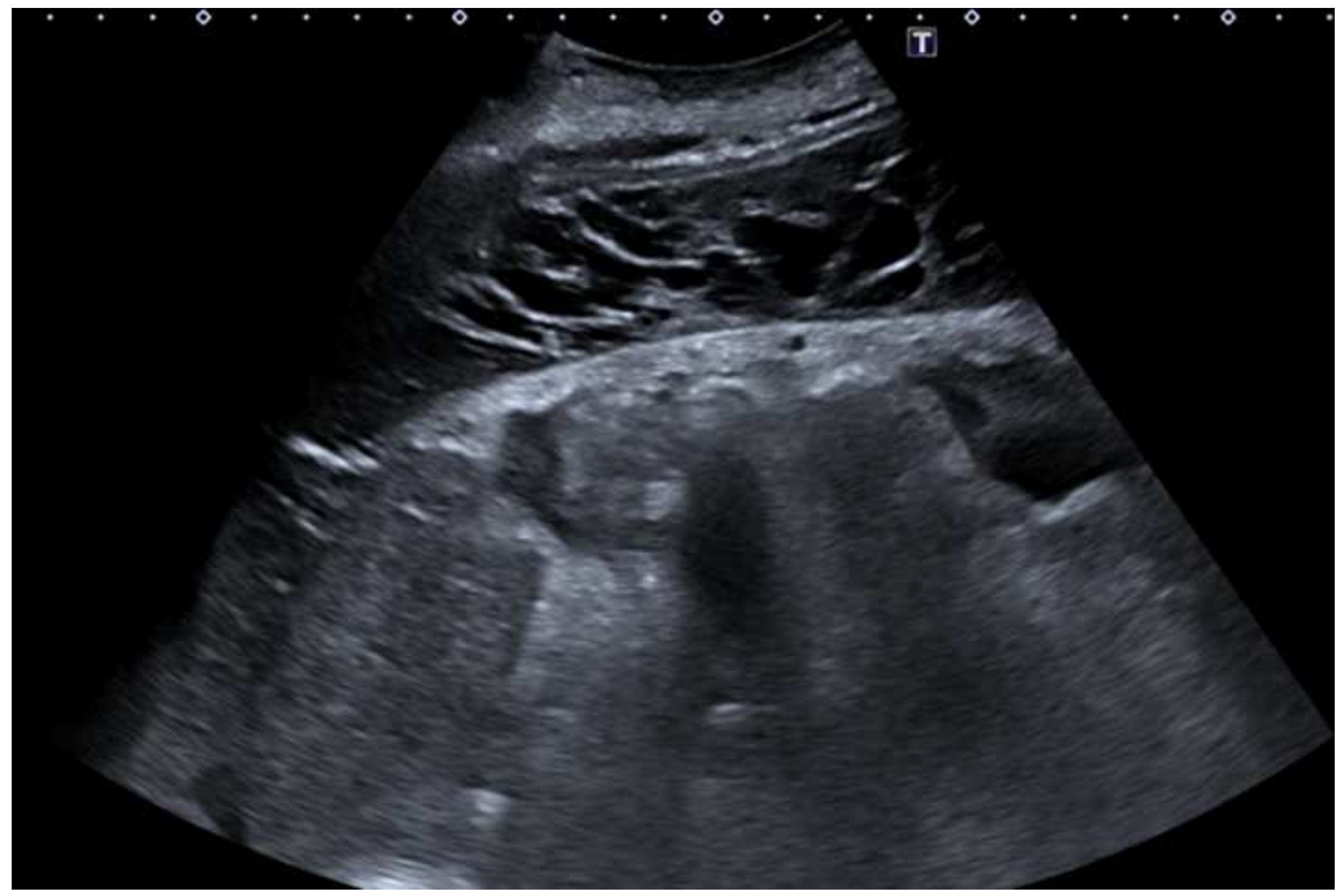




\section{wnload high resolution image}

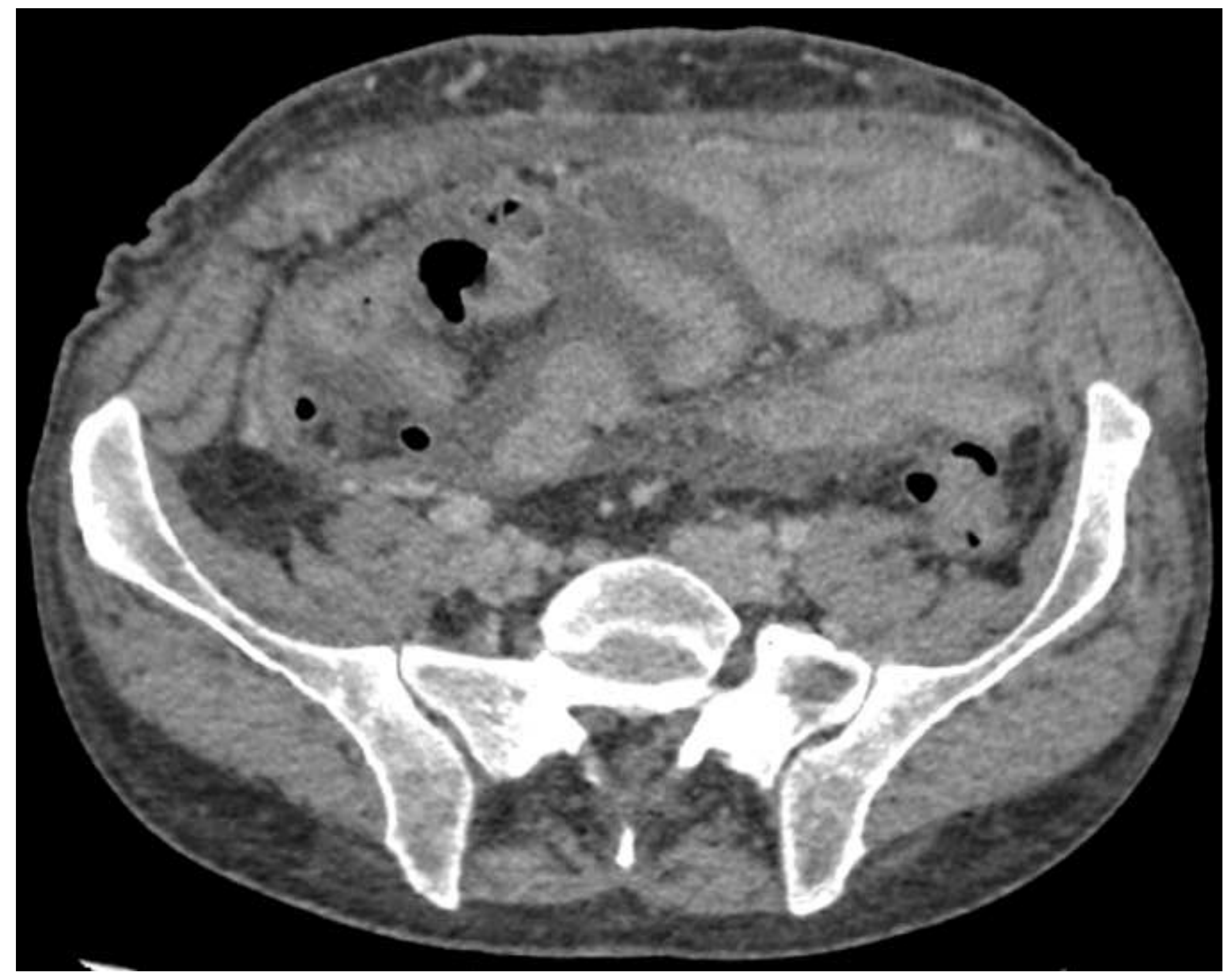

Figure 5.
Click here

-

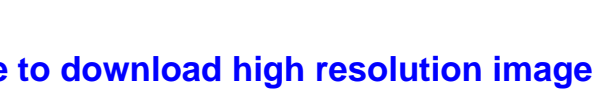

\section{e to}


Figure 1. Contrast-enhanced CT scan: Loculated ascites localised predominaltely in the right abdomen. There is a diffuse thickening and enhancing of peritoneum in favor of peritonitis.

Figure 2. US examination: Multiple ascites loculations caused by the fibrin strandings. US drainage of a loculated area.

Figure 3. US drainage of a large loculated area.

Figure 4A. US examination: Loculated ascites before the intra-abdominal fibrinolysis.

Figure 4B. US evaluation 3 days after the intra-abdominal fibrinolysis showing the reduction of the fibrin strandings.

Figure 5. Five months post fibrinolysis. CT scan evaluation showing mild quantity of ascites, without any fibrin strandings. 